The Influence of Human Resources, Facilities and Infrastructure To Hemodialization Patient Satisfaction in Bhayangkara Hospital TK. 1 Raden Said Soekanto Jakarta

\title{
The Influence of Human Resources, Facilities and Infrastructure To Hemodialization Patient Satisfaction in Bhayangkara Hospital TK. 1 Raden Said Soekanto Jakarta
}

\author{
Kesty Rama Danty ${ }^{{ }^{*}}$ \\ ${ }^{1}$ Universitas Satyagama, Jakarta, Indonesia
}

\begin{abstract}
Hemodialysis is one type of therapy for kidney failure patients that many suffer from in Indonesia. Identification of problems in this study consisted of a lack of nurses and non-medical staff working in the Hemodialysis room, lack of facilities and infrastructure in Hemodialysis rooms such as toilets for visitors, narrow hemodialysis space so that beds between patients were close together, consultation room for patients with doctors, the location of Hemodialysis rooms is less strategic than major roads, and there is no isolation room specifically for Hepatitis B patients. Phenomena that often occur in some hospitals, especially related to the ability of human resources in caring for patients who already have Hemodialysis training certificates as a benchmark for the ability of ideal and actual human resources. Another problem is that the application of technology that has not been optimal has an effect on patient satisfaction, an environment that is not yet conducive which has an effect on patient satisfaction and the provision of incentives to HD room staff is inadequate which influences service and impacts patient

This research is needed to study and analyze how much influence human resources and facilities and infrastructure have on the satisfaction of hemodialysis patients at TK I Raden Said Soekanto Bhayangkara Hospital, Jakarta. The design of the research is using descriptive analysis and regression analysis. To meet the research objectives set, the research design used a survey method with a quantitative approach using questionnaires to collect data. The construction of a questionnaire or list of questions is based on perception.

The results showed a positive and significant relationship between Human Resources and Hemodialysis Patient Satisfaction at Bhayangkara Tk.I Hospital, Soekanto Hospital, East Jakarta. Correlation of test results in the form of strong positive results. Human resources have a contribution of $42.6 \%$ to patient satisfaction. The results also showed a positive and significant relationship between Facilities and Infrastructure on Hemodialysis Patient Satisfaction at Bhayangkara Tk.I Hospital, Soekanto Hospital, East Jakarta. Correlation of test results in the form of strong positive results. Facilities and infrastructure contributed $43.7 \%$ to patient satisfaction. The results showed a positive and significant relationship between human resources and infrastructure simultaneously to Hemodialysis Patient Satisfaction at Bhayangkara Tk.I Hospital, Soekanto Hospital, East Jakarta. Human resources and infrastructure simultaneously contribute $56.9 \%$ to patient satisfaction.
\end{abstract}

Keywords: Facilities and Infrastructure, Descriptive Analysis, Human Resources, Satisfaction of Hemodynamic Patients

\section{Introduction}

Hemodialysis is one type of therapy for kidney failure patients that many suffer from in Indonesia. Hemodialysis is used to replace some kidney function. Hemodialysis patients need special care because they have to spend quite a lot of time in the hospital, which is 2 to 3 dialysis sessions per week, with each dialysis session

* Corresponding author. Email address: raditatech@yahoo.com 
taking 4 to 5 hours. Because of each year the incidence of chronic kidney failure requiring renal replacement therapy in the form of dialysis is increasing, it is necessary to increase the number of dialysis services in health care facilities at Bhayangkara Hospital TK.I Soekanto Hospital.

Identification of problems in this study consisted of a lack of nurses and nonmedical staff working in the Hemodialysis room, lack of facilities and infrastructure in Hemodialysis rooms such as toilets for visitors, narrow hemodialysis space so that beds between patients were close together, consultation room for patients with doctors, the location of Hemodialysis rooms is less strategic than major roads, and there is no isolation room specifically for Hepatitis B patients. Phenomena that often occur in some hospitals, especially related to the ability of human resources in caring for patients who already have Hemodialysis training certificates as a benchmark for the ability of ideal and actual human resources. Another problem is that the application of technology that has not been optimal has an effect on patient satisfaction, an environment that is not yet conducive which has an effect on patient satisfaction and the provision of incentives to HD room staff is inadequate which influences service and impacts patient

The current condition and situation of Human Resources at Sukanto Hospital are suspected to be in a problem, namely the lack of nurses and non-medical personnel working in the Hemodialysis Room of Bhayangkara Hospital TK.I Soekanto Hospital and relating to the ability of human resources in caring for patients who already have Hemodialysis training certificate as a benchmark of ideal and actual human resource capabilities. Human resources needed in hemodialysis services consist of internal medicine specialists (hypertensive kidney consulants), internal medicine specialists, other health professionals (general practitioners and hemodialysis nurses), technicians who understand the hemodialysis machine, pharmacists who understand dialysate fluid and other equipment needed for hemodialysis, as well as other human resources as needed.

On the other hand, the lack of facilities and infrastructure in the hemodialysis room such as toilets for visitors, the narrow space of the hemodiálisis so that the beds between patients are close together, the patient consultation room with the doctor, the location of the hemodialysis room is less strategic far from the main road, and there is no special isolation room for patients Hepatitis B.

Patient satisfaction depends on the ability of human resources in handling patients and the completeness of facilities and infrastructure in hospitals that are related to patients.

\section{Methodology}

Survey research is a valuable tool for use in scientific research which aims to develop new theoretical models. Within this approach we can distinguish two main categories of surveys:

1. Explorative, also known as descriptive: these surveys are meant to study the current state of a phenomenon, in a chosen population. It is the first step in a scientific investigation. This category also includes all the data collected to describe the results of a certain phenomenon.

2. .Explicative, also known as relational: these surveys are meant to test a certain hypothesis and the relationships among the variables which are the object of the investigation. Hypotheses may just prove the existence of a specific relationship, or also infer the existence of a positive or a negative influence.

Survey research is therefore an important empirical tool which can be used when studying. Here is a short synthesis of the main steps of this approach setting of the theoretical background, selection of the research methodology, definition of the data 
The Influence of Human Resources, Facilities and Infrastructure To Hemodialization Patient Satisfaction in Bhayangkara Hospital TK. 1 Raden Said Soekanto Jakarta

collection approach, data collection, selection of tools for the analysis, analysis of the collected data.

\section{Research Model}

The data analysis model of this study uses simple and multiple linear regression as shown in Figure 1.

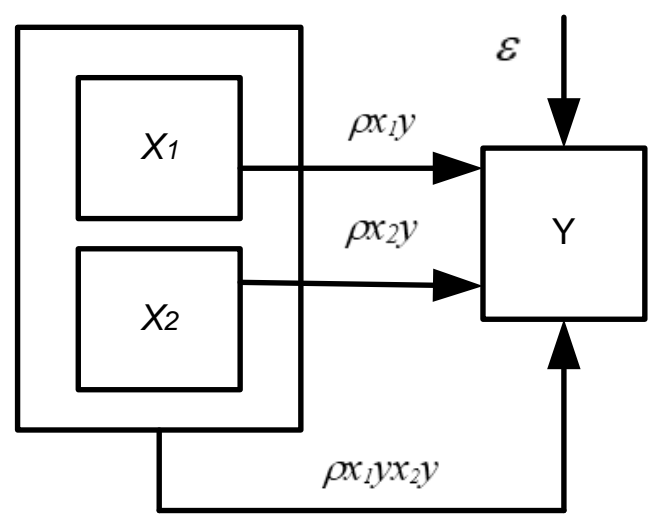

Figure 1 Research Model

Written numeric's data as follows:

$X_{1} \quad=\quad$ Human resources (independent variable)

$X_{2}=$ Facilities and Infrastructure (independent variable)

$Y=\quad$ Patient satisfaction at Bhayangkara Tk.I Hospital, Soekanto Hospital (dependent variable)

$\rho X_{1} Y=$ The structural parameters of the effect of $X_{1}$ to $Y$

$\rho P X_{2} Y=$ The structural parameters of the effect of $X_{2}$ to $Y$

$\rho X_{1} Y X_{2} Y=$ The structural parameters influence $X_{1}$ and $X_{2}$ together to $Y$

$\varepsilon=$ Epsilon (other factors outside of research)

\section{Discussion}

\subsection{Data Description}

A description of the results of the study was carried out so that a clear description of the statements of the respondents could be obtained from the variables included in this study, namely the influence of Human Resources and Facilities and Infrastructure on the Patient Satisfaction of Hemodialysis

\section{a. Age Level}

The age level of hemodialysis patients at Soekanto Hospital, East Jakarta was mostly $36-40$ years old (28\%), and (19\%) aged 31-35 years. Only 9\% are aged between 20-25 years, according to the following graph. 


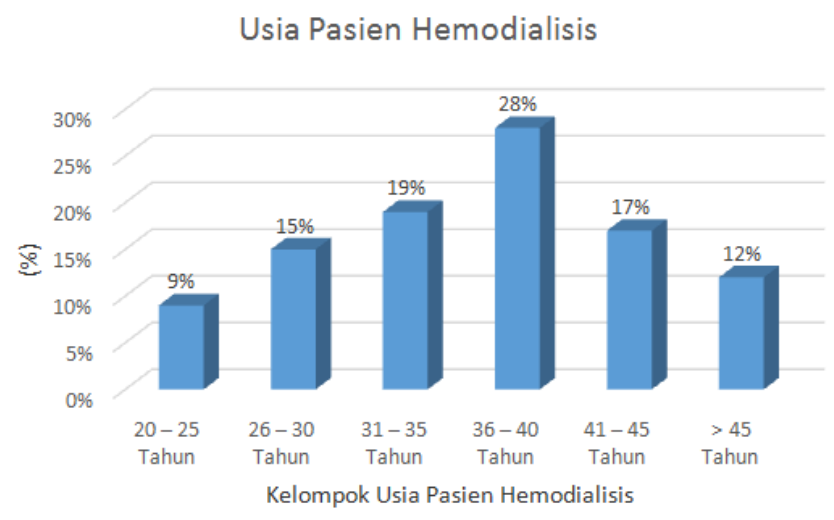

Figure 2 Percentage Graph of Patient Age Level (Respondents)

\section{b. Gender}

Hemodialysis patients were male $(34 \%(63 \%)$, the remaining 20 were female employees $(37 \%)$, according to the following pie chart.

\section{Pasien berdasarkan jenis kelamin}

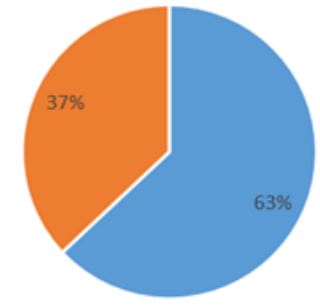

" Laki-taki " Perempuan

Figure 3 Percentage Gender Graph of Respondents

\section{c. Level Education}

Most respondents (68\%) have a Bachelor's Degree (S1), Diploma Three (D3) level occupies the second highest number $(21 \%)$ and lastly 5 people $(11 \%)$ with a Public High School education.

Tingkat Pendidikan Pasien



Figure 4 Graph of Respondent Education Level

\subsection{Hypothesis Test}

a. The effect of Human resources to Patient satisfaction

Correlation value $(R)$ determination of Human Resources $\left(X_{I}\right)$ with patient satisfaction $(Y)$ of 0.661 is classified as a strong positive correlation. The HR coefficient indicates a contribution of 0.426 or $42.6 \%$ to patient satisfaction. From these data it is proven that there is a strong positive relationship between HR variables on customer satisfaction. With $t_{\text {count }}$ greater than $t_{\text {table }}$ and p.sig $<0.05$ shows the significance of the influence of the HR independent variable on the dependent variable 
Patient Satisfaction. Based on the above test it can be proven that there is a positive and significant effect between HR on Patient Satisfaction.

\section{b. The effect of Facilities and Infrastructure to Patient satisfaction}

Correlation value $(R)$ determination of Facilities and Infrastructure $\left(X_{2}\right)$ with Patient satisfaction $(Y)$ of 0.669 is classified as a strong positive correlation. The coefficient of Facilities and Infrastructure and Infrastructure shows a contribution of 0.437 or $43.7 \%$ to patient satisfaction. From these data it is proved that there is a strong positive relationship between the variable Facilities and Infrastructure on customer satisfaction. With a $t_{\text {count }}$ greater than $t_{\text {table }}$ and $p . s i g<0.05$ indicates the significance of the influence of the independent variable Facilities and Infrastructure on the dependent variable Patient Satisfaction. Based on the above test it can be proven that there is a positive and significant effect between Facilities and Infrastructure on Patient Satisfaction.

\section{c. The effect of Human resources, Facilities and Infrastructure together to Patient satisfaction}

Correlation value $(R)$ determination of $\mathrm{HR}\left(X_{I}\right)$ and Facilities and Infrastructure $\left(X_{2}\right)$ simultaneously with Patient satisfaction $(Y)$ of 0.765 are classified as strong positive correlation. The HR coefficient and means and infrastructure simultaneously showed a contribution of 0.569 or $56.9 \%$ to patient satisfaction. From these data it is proven that there is a strong positive relationship between the variables HR and Facilities and Infrastructure simultaneously on customer satisfaction. With a $t_{\text {count }}$ greater than $t_{\text {table }}$ and p.sig $<0.05$ shows the significance of the effect of the independent variable HR and Facilities and Infrastructure simultaneously on the dependent variable Patient Satisfaction. Based on the above test it can be proven that there is a positive and significant effect between HR and Facilities and Infrastructure simultaneously on Patient Satisfaction.

\section{Conclusion}

1. There is a positive and significant relationship between Human Resources and Hemodialysis Patient Satisfaction at Bhayangkara Hospital Tk.I Soekanto Hospital, East Jakarta. Correlation of the test results in the form of strong positive results. Human resources contributed $42.6 \%$ to patient satisfaction.

2. There is a positive and significant relationship between Facilities and Infrastructure on Hemodialysis Patient Satisfaction at Bhayangkara Hospital Tk.I Soekanto Hospital, East Jakarta. Correlation of the test results in the form of strong positive results. Facilities and Infrastructure contributed $43.7 \%$ to patient satisfaction.

3. There is a positive and significant relationship between human resources and facilities and infrastructure simultaneously to the satisfaction of hemodialysis patients at Bhayangkara Hospital, Tk.I, Soekanto Hospital, East Jakarta. Correlation of the test results in the form of strong positive results. Human resources and infrastructure simultaneously contribute $56.9 \%$ to patient satisfaction

\section{References}

Aditama, T. Y. (2006). Manajemen Administrasi Rumah Sakit ( ${ }^{\text {nd }}$ Edition). Jakarta: UI-Press.

Apospori, E., Nikandrou, I., Brewster., \& Papalexandris, N. (2008). HRM and Organizational Performance in Northern and southern Europe. International Journal of Human Resource Management, 19(7), 1187-1207. 
Berman, S. (2016). Why Human Resources Policies and Practices are Critical to Improving The Patient Experience. Patient Experience Journal.

Dansky. (1997). Patient satisfaction with ambulatory healthcare services: waiting time and filling time. Hospital \& Health Services Administration, 42(2), 165-177.

Haryanti, K., \& Hadi, S. (2000). Hubungan Persepsi Mutu Pelayanan dan Nilai Konsumen dengan Kepuasan Konsumen. Psikodimensia, 1(1), 46-56.

Junaidi, P. (1995). Pengantar Analisis Data. Jakarta: Rineka Cipta.

Karassavidou, E., Glaveli. N., \& Papadopoulus, C. T. (2009). Quality in NHS Hospitals: No One Knows Better Than Patients. Measuring Business Excellence, 13, 34-46.

Kotler, P., \& Keller, K. L. (2012). Marketing Management. New Jersey: Pearson Education, Inc.

Moenir, A. S. (1992). Manajemen Pelayanan Umum di Indonesia. Jakarta: Bumi Aksara.

Nugraha, I. R. K. (2016). Kompetensi Sumber Daya Manusia Dalam Penyelenggaraan Hemodialisis di Rumah Sakit Dihubungkan Dengan Asas Perlindungan Hukum. SOEPRA Jurnal Hukum Kesehatan, 2(1).

Oliver, R. L. 2010. Satisfaction: A Behavioral Perpective on The Customer. New York: McGraw-Hill.

Susanti, L., \& Achmad, E. K. (2018). Systematic Review: Kepuasan Pasien Gagal Ginjal terhadap Pelayanan di Unit Hemodialisis Ethos (Jurnal Penelitian dan Pengabdian Masyarakat), 6(2), 343-350.

Terry, G. R., \& Rue, L. W. (2014). Dasar-dasar Manejemen. Jakarta: PT.Bumi Aksara. 